\begin{tabular}{lcc}
\hline \hline VOLUME 47 & 2018 & NUMBER 1 \\
\hline \hline
\end{tabular}

\title{
ARTICLES
}

\section{THE OTHER SPACE RACE: SOME LAW AND ECONOMICS OF} CELESTIAL RESOURCE APPROPRIATION

Alexander William Salter*

\section{TABLE OF CONTENTS}

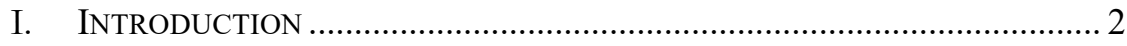

II. LAW AND ECONOMICS OF CELESTIAL LAND APPROPRIATION ................ 8

III. The SPace Race With Heterogeneous ClaimantS ....................... 11

IV. But What About the Legal System? ........................................... 13

V. CONCLUSION: What SHOULD SOVEREIGNS Do?................................. 17

*Assistant Professor of Economics, Rawls College of Business, Texas Tech University. Comparative Economics Research Fellow, Free Market Institute, Texas Tech University 


\section{INTRODUCTION}

On February 6, 2018, SpaceX successfully launched its new Falcon Heavy rocket. The rocket's maiden flight could very well signal the arrival of a new stage of space exploration and commerce, one led primarily by the private sector. Although SpaceX made use of government launch facilities - the test took place at NASA's Space Center at Cape Canaveral, FL - the technology itself is privately developed. "For the first time since the United States and Soviet Union began their race into orbit, the world's most powerful rocket was designed and built by a private corporation."

Space has typically been the domain of governments, rather than private actors, but in recent years the private sector has become an increasingly important contributor to space activities. In 2016, the total size of the global space economy was $\$ 329$ billion, up from $\$ 323$ billion the year before. ${ }^{2}$ Commercial spending accounted for $\$ 253$ billion, approximately $76 \%$ of the space economy. Government spending on space activities decreased slightly but was more than compensated by the increase in private expenditures. ${ }^{3}$ In 2017 , private equity flows into the space sector totaled between $\$ 2.5$ billion and $\$ 3.9$ billion $^{4}$; with the continued commercial development of space technologies, this figure is likely to grow. From commercial launch services to more exotic operations such as space tourism and asteroid mining, private enterprise is shaping up to be a critical driver of outer space activity, one that may even outpace governments.

But even if the public sector remains the leader in space development, the increased prominence of private sector activities does pose several economic and legal challenges. The problem posed by increased private enterprise in outer space can best be understood with reference to the current body of law governing space activities. In international space law, sovereign states are parties to treaties governing the use of outer space by states and the private organizations within those states' jurisdiction. While there have been several international treaties on the use of space by sovereigns and their citizens, the

\footnotetext{
${ }^{1}$ Peter Apps, Commentary: SpaceX Launch Opens New Frontier in Space Commerce, REUTERS (Feb. 6, 2018), https://www.reuters.com/article/us-apps-space-commentary /commentary-spacex-launch-opens-new-frontier-in-space-commerce-iduskbn1fq38w.

2 Press Release, Space Foundation, Space Foundation Report Reveals Global Space Economy at \$329 Billion in 2016 (Aug. 3, 2017), https:// www.spacefoundation.org/news/ space-foundation-report-reveals-global-space-economy-329-billion-2016.

3 Id.

4 Jeff Foust, How Long Will the Money Keep Flowing?, The Space Review (Feb. 5, 2018), http://www.thespacereview.com/article/3425/1.
} 
most important remains the 1967 Outer Space Treaty. ${ }^{5}$ The first two Articles of this treaty indicate that private-led initiatives to explore and commercialize space may be contrary to international law and the interests of states that are parties to the agreements from which such law stems.

Article I of the Outer Space Treaty (hereafter OST) reads, in part:

The exploration and use of outer space, including the moon and other celestial bodies, shall be carried out for the benefit and in the interests of all countries, irrespective of their degree of economic or scientific development, and shall be the province of all mankind... Outer space, including the moon and other celestial bodies, shall be free for exploration and use by all States without discrimination of any kind, on a basis of equality and in accordance with international law, and there shall be free access to all areas of celestial bodies. ${ }^{6}$

Article II reads: "Outer space, including the moon and other celestial bodies, is not subject to national appropriation by claim of sovereignty, by means of use or occupation, or by any other means." ${ }^{7}$

Article II is more obviously problematic for private enterprise. This article clearly forbids the extension of territorial jurisdiction to space. However, this may restrict governments' ability to define and enforce private property rights, which would have a deleterious effect on space commercialization. This is certainly true with real property. As argued by White, "in common law countries such as the United States, legal theory dictates that the government must have sovereignty over territory before it can confer title on its citizens. Consequently, traditional real property rights [in outer space] are inconsistent with this theory." ${ }^{8}$ However, even other kinds of property, such as the resources gained from an asteroid mining operation, may be implicitly forbidden under international law. ${ }^{9}$ Tronchetti provides a concise explanation:

Under international law property rights derive from States. In fact, in order to exist, property rights require a superior

\footnotetext{
5 Treaty on Principles Governing the Activities of States in the Exploration and Use of Outer Space, Including the Moon and Other Celestial Bodies, Jan. 27, 1967, 610 U.N.T.S. 205 [hereinafter OST].

${ }^{6} I d$.

${ }^{7} I d$.

${ }^{8}$ Wayne White, The Legal Regime for Private Activities in Outer Space, in SpacE: THE Free-Market Frontier 83 (Edward L. Hudgins ed., 2002).

9 Virgiliu Pop, Appropriation in Outer Space: The Relationship Between Land Ownership and Sovereignty on the Celestial Bodies, 16 SpaCe Policy 275, 281 (2000).
} 
authority, a State, entitled to attribute and enforce them. This, of course, means that States need to have property rights themselves first before being able to recognize them to other subjects. Thus, any US attempt to confer property rights over asteroid resources to its private companies would indirectly signify that the United States attribute to itself ownership over those resources. Such an arbitrary attribution would collide with the non-appropriation clause, also because, as previously pointed out, no consensus on whether space resources can be removed and exploited exists. ... Under terrestrial mining law a State allocates to public and private companies the right to exploit the natural resources within its territorial jurisdiction. Such a State has, indeed, the title to do so because the resources are located inside its territory. By attributing to a private company the right to mine an asteroid and to acquire property rights over the extracted resources, the United States could be accused of considering that asteroid as part of its territory, thus violating the non-appropriation principle. ${ }^{10}$

Economists have long emphasized the importance of private property rights for social wealth creation and generalized economic growth, ${ }^{11}$ so this apparent barrier to space commerce is concerning. However, it is also important to note the context surrounding the agreements to space treaties has changed significantly since OST. OST was drafted and signed during the height of the Cold War. Many of its provisions can be read as a way for the United States and the Soviet Union to commit to not escalating armed conflict by extending their military and economic rivalry to space. ${ }^{12}$ Today's concerns are much more in the form of clashes of 'soft power' and rivalry for space exploitation, rather than as a means to armed conflict. States with capable space programs, such as the Russian Federation and the People's Republic of China, could position themselves to capture the benefits flowing from the commercialization of space. In addition, the small state of Luxembourg has recently started developing legal infrastructure for protecting space

${ }^{10}$ Fabio Tronchetti, Private Property Rights on Asteroid Resources: Assessing the Legality of the Asteroids Act, 30 SPACE POLICY 193, 194 (2014).

11 See Adam Smith, An Inquiry Into the Nature And Causes of the Wealth Of Nations (1776); Ludwig Von Mises, Human Action: a Treatise on Economics (1949); Armen A. Alchian \& Harold Demsetz, The Property Right Paradigm, 33 The Journal of ECONOMic History 16 (1973); Douglass CeCil North, Institutions, Institutional Change and Economic Performance (1990).

12 See Peter Jankowitsch, Frans van der Dunk \& Fabio Tronchetti, The Background and History of Space Law, in HandBoOK OF SpaCE LAw 1,3 (2015); Thomas E. Simmons, Deploying the Common Law to Quasi-Marxist Property on Mars, 51 Gonz. L. REv. 25, 78 (2015). 
enterprise's property rights to celestial resources, as a means of incentivizing those enterprises to locate themselves within its jurisdiction. Whatever the de jure status of private property rights to outer space real estate and other resources is, de facto there is a strong incentive for states to promote commercial development to grow their power and prestige. Public international law, including space law, must be enforced by the voluntary compliance of the parties themselves. ${ }^{13}$ There is no international supersovereign to compel obedience to the terms of previous treaties. Because the world's states are in a 'state of nature' with respect to each other, if the benefits of cultivating space commerce exceed the costs in terms of lost international goodwill, sovereigns will try to find a way to render their activities compatible, if not with the spirit, then the letter of international law as expressed in treaties. In all realms of human behavior, when the wealth gained in creating and enforcing property rights exceed the costs, there are strong incentives for economic and political actors to find ways to do so. ${ }^{14}$ Thus if the potential gains become large enough, the OST provisions intended to protect space from private appropriation may no longer be self-enforcing.

The stage seems set for another space race. The potential wealth from space commercialization is enormous, and it seems the rewards will disproportionately accrue to the parties that position themselves to be 'first movers.' An economic perspective on this issue suggests a commercial space race could be globally detrimental, and contrary to the intent of Article I's call for space activities to be carried out in "the interests of all countries, irrespective of their degree of economic or scientific development. .." ${ }^{15}$ In analyzing the economics of legal rules governing the appropriation of unowned resources, economists have concluded that there are significant differences in the incentives created by property rights to resources that must be created versus resources that already exist and must be appropriated. ${ }^{16}$ It is in society's interest to give pizza parlors a property right to the pizzas they make, because this creates strong incentives for the creation and sale of pizzas.

13 Alexander W. Salter \& Peter T. Leeson, Celestial Anarchy: A Threat to Outer Space Commerce, 34 CAто J. 581, 593 (2014); Alexander W. Salter, Ordering the Cosmos: Private Law and Celestial Property Rights, 82 J. AIR L. \& Com. 311, 319 (2017) (Showing that while all international law, and hence the portion of international law dealing with space, must be self-enforcing, not all international law is customary. In addition to custom, the sources of international law include treaties, general legal principles, and, to a lesser extent, the writings of highly regarded scholars); Frans von der Dunk, International Space Law, in HANDBOOK OF SPACE LAW (2015) (providing a cogent explanation of how the various sources of international law have informed space law).

14 Harold Demsetz, Toward a Theory of Property Rights, 57 The AMERICAN ECONOMIC REVIEW 347 (1967).

15 OST, supra note 5.

16 David D. Friedman, Laws Order: What ECONOMics has to do With LAW AND WhY IT MATTERS ch. 10 (2001). 
So long as pizza parlors can make and sell pizzas profitably, both the pizza parlor and society at large are wealthier. But the story is not so simple with resources such as land or sub-surface minerals. Because the gains from these resources are not created, but appropriated, parties interested in capturing the benefits flowing from the resources have an incentive to waste resources in racing to be the first to make a claim. An extreme result is that the entire value of the wealth potentially existing in owned resources can be lost to society in this process. Precisely because the benefits to being a pioneer in space exploration, colonization, and development are potentially massive, there is a corresponding benefit for wastefully using resources to increase the chance of being a first claimant. Sovereigns and the commercial entities they oversee thus have strong private incentives to race to space, without necessarily considering the social costs ("...the benefits and interest of all countries...") of their behavior in terms of wasted resources. ${ }^{17}$

This paper explores the problem of appropriation of celestial resources using tools from the economic analysis of law. It will examine the conditions under which the appropriation of resources, such as minerals, is socially detrimental, and ascertain whether those conditions are in fact true for outer space. In doing so, this paper contributes to three separate but related literatures. The first literature, which has several older contributions but is in the early stages of a renaissance, explores the governance and use of space in international relations and international organization. ${ }^{18}$ The second literature, probably the most developed in recent years, focuses on space commerce and

17 OST, supra note 5.

18 See Lincoln P. Bloomfield, Outer Space and International Cooperation, 19 International Organization 603 (1965); Philip De Man, State Practice, Domestic Legislation and the Interpretation of Fundamental Principles of International Space Law, 42 Space Policy 92 (2017); Nader Elhefnawy, Territorializing Space? Revisiting an Old Idea, 1 Astropolitics 55 (2003); Philip C. Jessup \& Howard J. Taubenfeld, Outer Space, Antarctica, and the United Nations, 13 InTERnATIONAL OrganiZATION 363 (1959); Klaus Knorr, On the International Implications of Outer Space, 12 WorLd PoliTiCs 564 (1960); Stephen D. Krasner, Global Communications and National Power: Life on the Pareto Frontier, 43 World Politics 336 (1991); Karl Leib, State Sovereignty in Space: Current Models and Possible Futures, 13 Astropolitics 1 (2015); M. J. Peterson, The Use of Analogies in Developing Outer Space Law, 51 InTERnATIONAL OrganiZATION 245 (1997); Ian B. Perry, Law of Space resources and Operations on Celestial Bodies: Implications for Legislation in the United States, 15 Astropolitics 1 (2017); Konrad Szocik, Tomasz Wójtowicz \& Leszek Baran, War or Peace? The Possible Scenarios of Colonising Mars, 42 Space Policy 31 (2017); Per Magnus Wijkman, Managing the Global Commons, 36 INTERNATIONAL ORGANIZATION 511 (1982). 
property rights. ${ }^{19}$ The third literature, which is the broadest, analyzes the economics of private governance and self-governance more generally. ${ }^{20}$

19 See Stephen Gorove, Interpreting Article II of the Outer Space Treaty, 37 FORDHAM L. Rev. 349 (1968); Wayne N. White, Jr., Real Property Rights in Outer Space, Space FUTURE (1998), http://www.spacefuture.com/Archive/Real_Property_Rights_In_Outer

_Space.Shtml; Ricky J. Lee, Reconciling International Space Law with the Commercial Realities of the Twenty-First Century, 4 Sing. J. INT'L \& COMP. L. 194, 237 (2000); Lawrence A. Cooper, Encouraging Space Exploration Through a new Application of Space Property Rights, 19 SpaCe PoliCy 111, 117 (2003); Michael J. Listner, The Ownership and Exploitation of Outer Space: A Look at Foundational Law and Future Legal Challenges to Current Claims, 1 Regent J. InT'L L. 75, 94 (2003); Carol R. Buxton, Property in Outer Space: The Common Heritage of Mankind Principle vs. the First in Time, First in Right Rule of Property, 69 J. AIR L. \& COM. 689, 705-07 (2004); Brandon C. Gruner, Comment, A New Hope for International Space Law: Incorporating Nineteenth Century First Possession Principles Into the 1967 Space Treaty for the Colonization of Outer Space in the Twenty-First Century, 35 Seton Hall L. Rev. 299, 355-57 (2004); Henry R. Hertzfeld \& Frans G. von der Dunk, Bringing Space Law into the Commercial World: Property Rights Without Sovereignty, 6 CHI. J. INT'L L. 81, 98-99 (2005); Rosanna Sattler, Transporting a Legal System for Property Rights: From the Earth to the Stars, 6 CHI. J. InT'L L. 23, 44 (2005); Jeremy L. Zell, Note, Putting a Mine on the Moon: Creating an International Authority to Regulate Mining Rights in Outer Space, 15 MinN. J. InT'L L. 489, 518 (2006); Nikhil D. Cooper, Note, Circumventing Non-Appropriation: Law and Development of United States Space Commerce, 36 Hastings Const. L. Q. 457, 482 (2009); Alan Wasser \& Douglas Jobes, Space Settlements, Property Rights, and International Law: Could a Lunar Settlement Claim the Lunar Real Estate it Needs to Survive?, 73 J. AIR L. \& COM. 37, 78 (2008); Tony Milligan, Property Rights and the Duty to Extend Human Life, 27 Space PoL'y 190, 193 (2011); Rand Simberg, Homesteading the Final Frontier: A Practical Proposal for Securing Property Rights in Space, COMPETITIVE ENTERPRISE INST. 1 (2012), https://cei.org/sites/default/files/Rand\%20Simberg\%20\%20

Homesteading\%20the\%20Final\%20Frontier.pdf; Rand Simberg, Property Rights in Space, THE NEw ATLANTIS (2012), https://www.thenewatlantis.com/publications/property -rights-in-space; Brian C. Weeden \& Tiffany Chow, Taking a Common-Pool Resources Approach to Space Sustainability: a Framework and Potential Policies, 28 SPACE Pol'y 166, 172 (2012); Matthew Feinman, Mining the Final Frontier: Keeping Earth's Asteroid Mining Ventures From Becoming the Next Gold Rush, 14 PitT. J. TeCH. L. \& Pol'y 202, 234-35 (2014); Lauren E. Shaw, Asteroids, the New Western Frontier: Applying Principles of the General Mining Law of 1872 to Incentive Asteroid Mining, 78 J. AIR L. \& COM. 121, 168-69 (2013); Thomas R. Irwin, Note, Space Rocks: A Proposal to Govern the Development of Outer Space and its Resources, 76 Oніо ST. L.J. 217, 245-46 (2015); Andrew Linter, Extraterrestrial Extraction: The International Implications of the Space Resource Exploration and Utilization Act of 2015, 40 FLETCHER F. WORLD AFF. 139, 15354 (2016); Alexander William Salter, Space Debris: A Law and Economics Analysis of the Orbital Commons, 19 StAN. TECH. L. ReV. 221, 237-38 (2016).

20 See David Friedman, The Machinery of Freedom: Guide to a Radical Capitalism, at xii-xv (3d ed. 2014); Robert C. Ellickson, Order Without Law: How Neighbors Settle Disputes 1-11 (1991); Terry L. Anderson \& Peter J.Hill, The not so Wild, Wild West: Property Rights on the Frontier 4-5 (2004); Bryan Caplan \& Edward P. Stringham, Privatizing the Adjudication of Disputes, 9 THEORETICAL INQUIRIES L. 504, 599 (2008); Benjamin W. Powell \& Edward P. Stringham, Public Choice and the Economic Analysis of Anarchy: A Survey, 140 Pub. CHolce 503, 504 (2009); Peter Boettke, 
The remainder of this paper proceeds as follows: Section 2 surveys the economic problems with land appropriation. Section 3 highlights the conditions under which these problems are ameliorated, and whether outer space is an environment where we can expect those conditions to prevail. Section 4 builds on these insights to discuss the potential for private, selfenforcing law to govern private property rights in space, in a manner conducive to generalized wealth creation but not inimical to treaty obligations. Section 5 concludes by discussing what public authorities ought, and more importantly ought not, do in light of these findings.

\section{LAW AND ECONOMICS OF CELESTIAL LAND APPROPRIATION}

Following standard terminology in economics, let "land" refer to valuable natural resources - the unproduced factors of production - such as physical space on the surface of a planet, or sub-surface asteroid minerals. The question before us is under what conditions are the appropriation of these resources by commercial entities (and, niceties of public international law aside, their state sponsors) beneficial to mankind? The reason this question, and all similar questions, are difficult to answer is that the normative standard "beneficial to mankind" is highly controversial. For the purposes of this paper, we focus on economic efficiency as a proxy for human welfare: the maximization of wealth available to society. The question thus becomes should we expect the first appropriation of celestial land to be wealth producing, or wealth destroying, for society?

Celestial resources are currently unowned. First possession rules for appropriating unowned resources have been the focus of significant intellectual attention, both philosophically and legally. Philosophically, John Locke $^{21}$ provided a powerful argument for the appropriation of unowned land through the application of human labor to that land. Legally, quasi-Lockean theories of property have been explicitly defended at least since Blackstone. ${ }^{22}$ In contemporary scholarship, Ellickson ${ }^{23}$ noted that the prevalence of first possession norms was due to a widely shared intuition about the rightness of such norms. Given the success of first appropriation rules, as evidenced by

Anarchism and Austrian Economics, 7 New Perspectives on Political ECONOMY 125 (2011); Edward P. Stringham \& Todd J. Zywicki, Hayekian Anarchism, 78 J. Econ. Behav. \& Org. 290, 293 (2011); Peter T. Leeson, Anarchy Unbound: Why SelfGovernance Works BetTer than you Think 1-3, 10 (2014); EdWARd P. Stringham, Private Governance: Creating Order in Economic and Social Life (2015).

21 John Locke, The Two Treatises of Civil Government 97 (1824).

22 William Blackstone, Commentaries on the Laws of England 304 (J.B. Lippencott Co. 1893).

${ }^{23}$ Robert C. Ellickson, Order Without Law: How Neighbors Settle Disputes 4$5(1991)$. 
their durability and longevity, the burden of proof would seem to rest on those who opposed the extension of first possession methods to celestial land.

However, not all scholars are supportive of first possession as a means of establishing ownership. Many scholars of law and economics, such as Anderson and Hill, ${ }^{24}$ Libecap and Wiggins,${ }^{25}$ and Williams ${ }^{26}$ have argued that first possession can be economically inefficient. "Unlike political philosophers and legal scholars, the criticism from economists has emphasized that first possession has the potential to dissipate wealth, either from a wasteful race to claim an asset or as a rule of capture which leads to over-exploitation." ${ }^{27}$

Imagine two commercial space companies, Deep Space Industries and Planetary Resources, are considering establishing a claim by first possession to an asteroid that they both anticipate contains valuable mineral deposits. ${ }^{28}$ Suppose both companies agree that these deposits will deliver a stream of benefits whose present discounted value, beginning in ten years, is $\$ 100$ million. The reason for the ten year delay is that, while both companies have the technology to land on the asteroid and establish a claim, they have not yet developed the mining technology that allows them to get the full $\$ 100$ million from the mineral deposits. Each company could establish an 'early' claimland on the asteroid and begin extraction before the maximization of value ten years hence - but only at the cost of destroying \$10 million in wealth for each year they are early. Setting aside complications arising from time discounting, how will each company behave? ${ }^{29}$

The efficient result, the one that maximizes the value of the asteroid's resources to society, is for the companies to wait ten years until they have the

24 Terry L. Anderson \& Peter J. Hill, The Race for Property Rights, 33 The JouRnAL of LAW AND ECONOMICS 177 (1990).

${ }^{25}$ Gary D. Libecap \& Steven N. Wiggins, Contractual Responses to the Common Pool: Prorationing of Crude Oil Production, 74 AMERICAN ECONOMIC REVIEW 87 (1984).

${ }^{26}$ Stephen F. Williams, The Requirement of Beneficial Use as a Cause of Waste in Water Resource Development, 23 NAT. ResourCES J. 7 (1983).

27 Dean Lueck, First Possession, in The New Palgrave Dictionary of Economics AND THE LAW 132 (Peter Newman ed., 1998).

28 See Frans von der Dunk, Asteroid Mining: International and National Legal Aspects, 26 Michigan State International Law Review, 83 (2017) (demonstrating the commensurability of asteroid mining with current public international law).

${ }^{29}$ More formally, the value to society of the resource is given by $V^{B}=$ $\int_{0}^{\infty} R(t)^{-(r-g) t} d t$, where $V^{B}$ is the value to society, $R(t)$ is the resource's flow value as a function of time, $r$ is the interest rate, and $g$ is the rate at which the resource value grows. This is the first-best scenario, as noted in Lueck, supra note 27. To the extent that establishing a claim is costly, the resource will remain unclaimed until the value of the asset increases sufficient to compensate for those costs. In the event of a single claimant, the above becomes $V^{S}=\int_{0}^{\infty} R(t)^{-(r-g) t} d t-C e^{-r t^{s}}$, where $V^{S}$ is the value of the resource to the single claimant, $C$ is the cost of establishing property rights, and $t^{S}$ is the time at which rights are established. Because of the costs of establishing a claim, $V^{S}<V^{B}$. 
technology necessary to mine the minerals without destruction of wealth. It is a matter of indifference to society which company establishes ownership; if either begins the mining operation at the appropriate time, society is $\$ 100$ million wealthier. But do the companies have the incentive to optimally time their actions? ${ }^{30}$ If Deep Space Industries plans on waiting the ten years, then it is in Planetary Resources' interests to preempt Deep Space Industries by a year in establishing the claim. In doing so, Planetary Resources guarantees itself $\$ 90$ million in private wealth, since establishing the claim early results in $\$ 10$ million being lost due to suboptimal timing. But if Planetary Resources had waited, they might not have gotten anything at all; adjusted for the probability of establishing an effective claim, it is almost certainly in Planetary Resources' interest to establish early and guarantee itself $\$ 90$ million. However, in doing so, society is $\$ 10$ million poorer. Resources worth $\$ 100$ million are now worth only $\$ 90$ million. Planetary Resources has no incentive to care about the $\$ 10$ million in destroyed wealth; their incentive is to get the most out of the asteroid minerals that they can. They reap the benefits; society at large bears the cost.

But this is not the end of the story: Deep Space Industries understands these incentives too. Knowing Planetary Resources has an incentive to establish a claim one year early, Deep Space preempts this by establishing a claim two years early. The result is $\$ 80$ million in private wealth for Deep Space Industries; $\$ 20$ million in destroyed wealth borne by society. Of course, this is not an equilibrium either. The race for asteroid minerals will continue until the full value of the asteroid wealth is dissipated, when both countries establish a claim as soon as possible. Instead of waiting ten years, or nine, or eight, both companies seek to take possession today. They try to capture for themselves whatever small value remains after the destruction of wealth in the race. $^{31}$

Thus it seems we have good reason to worry that a second space race, this one primarily commercial, may seriously attenuate the potential for private enterprise in space to create wealth for society. Importantly, the above process did not depend in any way on the resource in question. Land wealth, whether in the form of sub-surface minerals on asteroids or surface real estate on Mars, will be dissipated in the race to establish a claim if the strategic scenario above holds. The destruction of wealth from appropriations races certainly seems at odds with the provision in OST Article I stipulating that the "exploration and use of outer space, including the moon and other celestial bodies, shall be carried out for the benefit and in the interests of all countries..." What

30 Yoram Barzel, Optimal Timing of Innovations, 50 THE REVIEW OF ECONOMICS AND Statistics 348 (1968).

${ }^{31}$ The equilibrium condition is $V^{D}=\int_{t^{D}}^{\infty} R(t)^{-(r-g) t} d t-C e^{-r t^{D}}=0$, where $V^{D}$ is the dissipated value to society, $C$ is the cost of establishing property rights, and $t^{D}<t^{S}$ (see footnote 27) is the suboptimally early time at which rights are established. 
remains to be seen is whether we have reason to expect that a commercial space race will proceed along the lines of the above hypothetical.

\section{The Space Race with Heterogeneous Claimants}

Intriguingly, there are many plausible scenarios under which space wealth will not be dissipated in a costly race among claimants. ${ }^{32}$ The simplest is when claimants are heterogeneous. This means that claimants, due to personal characteristics such as resource endowments or existing technological capacity, are differentially capable of establishing a celestial land claim. The simplest way of describing this is that one claimant has a cost advantage over another claimant in establishing and enforcing property rights. If Deep Space Industries can establish a claim to asteroid minerals at lower cost than can Planetary Resources, then Planetary Resources knows it will lose the race to establish a claim. It thus has no incentive to expend the resources, which can only be a private loss. Deep Space Industries knows this as well, and so has no incentive to establish a claim inefficiently early, since it knows it is the only one in the race. The situation dovetails to the first-best value creation for society, minus the costs incurred by Deep Space Industries of establishing the claim.

What if potential claimants do not have complete information about each other's costs of establishing a claim? Even here, full dissipation of celestial wealth will not occur. In the event that neither party knows the other's costs, there will still be a race, but its destructive effects will be mitigated by the fact that one party is better at establishing a claim than the other. The party with the lower cost will find it economical to establish a claim earlier than the party with the higher cost and will earn private returns equal to the present discounted value of its cost advantage over its rival. In fact, the results are the same even if we assume parties can expect differential resource flows from the same claim, or if the value of the resource grows differentially depending on which party establishes a claim. "In the extreme case, where just one person has costs less than the net present value of the asset's flows, the firstbest outcome is achieved. Since only one person enters the race, there is no costly dissipation." 33

32 Yoram Barzel, The Capture of Wealth by Monopolists and the Protection of Property Rights, 14 International Review of LAW AND ECONOMics 393 (1994); Dean Lueck, The Rule of First Possession and the Design of the Law, 38 The Journal OF LAW AND ECONOMICS 393 (1995).

${ }^{33}$ In the event of incomplete information, $V^{i}=\int_{t^{i}}^{\infty} R\left[C_{j}-C_{i}\right] e^{-r t} d t$, where $i$ and $j$ index the competitors, with $i$ having the cost advantage. The larger $i$ 's cost advantage, the less the amount of wealth dissipated in the race. In the event of complete information, $V^{i}=V^{S}$ from footnote 27. See also Lueck, supra note 27, at 134. 
The question boils down to this: is the race for celestial land better characterized as competition among homogeneous claimants, or heterogeneous claimants? Economists' models of competition tend to emphasize extreme homogeneity among firms; in the limit, "perfect competition' is characterized by an industry with a large number of firms whose cost structure is identical. But this model is useful primarily because it can be juxtaposed with real-world competition, in which product and cost structure differentiation are the heart of rivalrous activity. Competition, properly understood, is not a state of affairs, but an active effort by firms to carve out a niche to best satisfy consumers. ${ }^{34}$ We have no reason to suspect this will be different for private space enterprises. Even two companies with a similar mission statement and business model, such as Deep Space Industries and Planetary Resources, will undoubtedly develop different approaches for solving similar problems. From patterns of internal finance and resource allocation, to investments in prospective technologies, the attempt by these firms to carry out their mission in competition with the other will pressure these firms to arrive at solutions whose formal propertiesnamely least-cost production - can be stated, but the particularities of strategy consistent with those formal properties can and will vary greatly. Note that differences in firm strategy can plausibly affect multiple variables that determine the firm's optimal appropriation time. For example, pursuing related yet dissimilar production technologies can result in different costs of establishing a claim, different values capable of being appropriated from the resources, and different rates at which the resource values change over time. In all likelihood, technological developments will affect all of these variables simultaneously.

It is also important to note that firms investing in technologies that will increase their capacity to appropriate celestial land have broader effects than those specified in the above problem situations. The race for celestial land is not just a resource sink. The technologies that firms develop to explore and appropriate space are in themselves wealth creating. In the context of the above problem situations, one way this could be incorporated is by explicitly linking investments in cost-reducing appropriations technologies to increases in the potential resource values to be appropriated. If claims to asteroid minerals are established through use, then investing in capacity to appropriate those resources is nearly identical to investing in capacity to channel them into production lines that are globally wealth enhancing. ${ }^{35}$

\footnotetext{
34 ISRAEL M. KiRZNER, COMPETITION AND ENTREPRENEURShIP (1973).

${ }^{35}$ In the language of economics, the race scenario presumes the returns from the resource and the costs of establishing a claim are exogenous. That is, they are parameters whose value for the model are given. In reality, both the returns and the costs of establishing property rights are endogenous: they are, at least partially, a result of profitseeking firms' choice in technology investments. A more complex model would
} 
The best characterization of the race for celestial land can be listed as follows:

- Potential claimants of celestial land will not be homogeneous. They will differ in crucial ways in terms of endowments and strategies that will result in nontrivial heterogeneity.

- Potential claimants of celestial land will be imperfectly informed about the values of the variables informing their competitor's optimal strategies. Firms with similar mission statements and business plans will probably be better informed about each other than more distant competitors. Deep Space Industries will know more about Planetary Resource's technological capacity (and vice versa), and hence claim costs, resource values, and resource growth rates, than it will about similar factors for SpaceX.

- The competition among potential claimants for cost-reducing appropriations technology will not result solely in sunk resources. The same technologies that will be used to establish a claim will be used to increase the value of a given claim. Investments in claim capacity and investments in utilization capacity are complements, not substitutes.

Each of these three points cut against wealth dissipation. In combination, they give us good reason to believe that celestial land wealth will not be wasted in a commercial space race. Undoubtedly, some resources will be used in ways ex ante that, ex post, turn out to be wasteful. But this is true of the competitive process for regular terrestrial industries as well. Competition is a discovery procedure, ${ }^{36}$ and the investments by private space enterprises in discovering the best way to deliver value to consumers is, both on its own and through the reduction in appropriation costs, a globally wealth-creating process. The tools of law and economics give us strong reasons to suspect that a commercial space race will not be economically inefficient.

\section{But What About the Legal System?}

The above examples assumed there was some system in place for defining and enforcing property rights to celestial land. This was necessary to demonstrate the economic implications of a commercial space race; why we might worry about such a race, and the ultimate mitigating factors that led us to conclude that private enterprise in space, at least on this issue, would be net

demonstrate how technological investment affects returns and costs, as well as introduce a production complementarity between returns and costs. However, that would take us far beyond the purposes of this paper.

${ }^{36}$ F.A. Hayek, Competition as a Discovery Procedure, 5 Q. J. Austrian Econ. 9 (2002); F.A. HAYeK, Individualism AND Economic ORder (Univ. Chicago Press 1948). 
wealth-creating. However, the existence of such a legal system cannot be taken for granted. OST Article II clearly forbids the extension of territorial jurisdiction to space. As mentioned previously, the implications for real property are clear: states cannot create and enforce such rights. ${ }^{37}$ However, it may also be the case that all state protection of celestial property rights is impermissible. ${ }^{38}$ "The majority view of Article I and Article II is property rights in celestial bodies, whether real or personal, are prohibited, including private persons." 39 Commenting on the update of United States commercial space legislation contained in the 2015 SPACE Act, ${ }^{40}$ which attempts to provide some security to space entrepreneurs by guaranteeing them the rights to space resources, Tronchetti writes:

The Space Resource Exploration and Utilization Act appears to collide with numerous provisions of the Outer Space Treaty. Particularly problematic is its relation with Article II of the Treaty. Under the Act the United States attributes itself the right to confer property rights over space resources to its private companies. Importantly, under international law, property rights require a superior authority, a State, entitled to attribute and enforce them. This signifies that States need to have property rights first before being allowed to attribute them to other entities. Seeing from this perspective the Act could be interpreted as an attempt by the United States to claim property rights over asteroid resources, a position which would clash with the non-appropriation clause, not lastly because, as described, there is no consensus on whether these resources can be appropriated and exploited. ${ }^{41}$

This is where political factors complicate the analysis concerning consequences of private enterprise in space. International law is unclear to what extent state-enforced private property rights in space are allowed. Clarification of existing law can only come about through cooperation among sovereign parties to OST. Because any such clarification requires de facto unanimity, at least among the serious spacefaring powers, the bargaining costs

37 OST, supra note 5.

38 This question takes precedence over whether asteroid minerals ought to be classified as real or personal property, which is not considered here.

${ }^{39}$ Michael J. Listner, Special Issue on Asteroid Mining, XII The Precis. Newsletter of Space Law \& Policy Solutions 3, (2017).

40 Spurring Private Aerospace Competitiveness and Entrepreneurship Act, Pub. L. No. 114-90, 129 Stat. 704 (2015).

${ }^{41}$ Fabio Tronchetti, The Space Resource Exploration and Utilization Act: A Move Forward or a Step Back?, 34 Space Policy 6, 9 (2015). 
over reaching an acceptable solution will undoubtedly be quite high. For example, the United States, the state currently with the greatest public and private space capacity, may favor immediate amendment of international law to favor appropriation of celestial resources by private parties, with private parties' activity supervised by public authorities as per OST. ${ }^{42}$ But states with up-and-coming programs, such as China, have an incentive to stall such renegotiations until they are in a position as favorable as the United States towards appropriating celestial resources. A vibrant space economy is a source of national prestige, as well as a resource base that political actors can use in pursuing both domestic and international agendas, so we can expect sovereigns to engage in some amount of international gamesmanship in the service of developing their domestic space economies. This ultimately increases international bargaining costs, rendering a treaty-based solution to previous legal ambiguities concerning space property rights unlikely.

But there is another possibility for the foundations of a commercial space legal regime. The ambiguity in current international law with respect to property rights ultimately hinges on state enforcement. The dominant view is that states are necessary to define and enforce property rights. But both theoretically and historically, this is not so. The literature on private governance and self-governance cited in the Introduction provides overwhelming evidence that a high degree of social order and commercial development can arise from privately governed agreements, even in the absence of a sovereign. The difficulties with establishing rights to celestial resources according to public law do not exist in the alternative of private law.

Salter and Leeson ${ }^{43}$ and Salter ${ }^{44}$ develop arguments showing why private law works in theory, and how it has in fact worked in history, with application to a private commercial order in outer space. Hertzfeld and von der Dunk ${ }^{45}$ develop a sophisticated legal argument showing how space property rights can be consistent with treaty obligations. Instead of merely repeating their arguments, this paper will consider the context in which private space law can arise and shape commercial development. For the purposes relevant to celestial land appropriation, this can be stated quite briefly. Ultimately the purpose of a private legal regime for space commerce is resolving disputes in as low-cost a manner as possible. ${ }^{46}$ Space entrepreneurs wish to make profits

42 The relevant portion is Article VI, which has not been explicitly discussed because it is only tangentially relevant to this paper's thesis.

43 Salter \& Leeson, supra note 13, at 584-592.

44 Salter, supra note 13.

${ }^{45}$ Henry R. Hertzfeld \& Frans G. von der Dunk, Bringing Space Law into the Commercial World: Property Rights without Sovereignty, 6 CHI. J. INT'L L. 81, 100 (2005).

46 To be more precise, legal disputes between space entrepreneurs will tend towards a least-cost equilibrium, including time foregone in adjudication that could be used in ordinary business operations. 
by exploiting celestial resources. It is inevitable that, at some point, their activities will come into conflict with each other. This will likely involve establishing who has what rights to the particular and separable portion of outer space resources: who may use surface space, who may access subsurface minerals, who may appropriate water, and under what conditions these claims are exclusive. Other issues will involve when such rights are alienable in the event they are claimed by the same party, and when the rights are bundled together (e.g., surface space with directly and shallowly subsurface minerals). These hypotheticals have something in common: they are all issues that domestic private law systems have been dealing with for hundreds, if not thousands, of years. Especially in common law systems, the law of property, contract, and torts are thick with precedents addressing precisely these dilemmas. Asteroid mining, though exotic, does not clearly differ from terrestrial mining in a legally relevant manner. Furthermore, these precedents are publicly available in various legal repositories, making it likely they can easily become public knowledge for any space firm capable of employing even a minimal legal staff. For example, Bell ${ }^{47}$ has developed an 'open source legal system' called Ulex, which specifies the relevant legal decisions that will determine how rights are allocated in the event of a dispute. It also specifies various procedural rules, which focus on the process by which disputes will be resolved. Procedurally, parties to a dispute each propose a remedy and select a judge. The two judges then select a third judge, and the panel decides upon one of the proposed remedies. In addition to the remedy, the loser pays the winner's adjudication costs. Substantively, the legal rules for allocating rights are taken from the Restatement of the Common Law (published by the American Law Institute) and the Uniform Commercial Code, as well as a few more highly specialized sources. Ulex is just one possible source that serves as a low-cost focal point for legal coordination in a private law system. Ultimately any system voluntarily consented to by the parties in question will do. The requirement of voluntary consent to the legal system will tend to select systems that have historically proven to be durable in the force of their decisions, and efficient in costs of operation.

The tricky issue seems to be enforcement. Granted legal precedents exist that can serve as effective means of allocating rights in the event of a dispute, what gives such decisions force in absence of a sovereign? Scholars of selfgoverning communities argue that voluntary self-regulation works best in the event of relatively small communities where community members can easily communicate with each other and can be expected to have repeated interactions with each other. This mechanism is called the discipline of continuous dealings. Suppose Deep Space Industries and Planetary Resources

47 Tom W. Bell, Your NeXt Government?: From the Nation State to Stateless NAtions app. B at 247-254 (Cambridge Univ. Press 2017). 
come into conflict over a particular mineral deposit, and consent to have their dispute arbitrated by a panel of industry experts. The panel rules against Deep Space Industries. It is true that Deep Space Industries could defy the panel, if the payoff from doing so is sufficiently large. But the costs of this antisocial behavior are also large; it will become public knowledge in the space commerce community that Deep Space Industries cannot be trusted to abide by its promises. Other organizations will no longer trust Deep Space Industries; they will no longer be willing to cooperate with it in potentially mutually profitable ventures. The consequence to Deep Space Industries from reneging on its agreements is significantly smaller future payoff potentials. Thus there is a mechanism that punishes antisocial behavior by firms, even in absence of a sovereign to do the punishing. If the board of Deep Space Industries is incredibly impatient, and is willing to forsake significant future benefits for a one-time present gain, the likely result will be reneging. But given the firms that make up the commercial space industry must make significant current investments in order to have the chance of financial returns decades down the line, it seems very unlikely that the space industry will be populated by impatient, opportunistic rogues. The nature of the cost investments in commercial space is a strong filter that selects for patient, cooperative behaviors. Reneging on arbitration agreements governed by private law will not likely be a concern.

In brief, there is nothing preventing space enterprises from voluntarily agreeing to a private legal system for adjudicating disputes. Private law can fill the gap created by the difficulties, in the international context, of formally amending public law. The economic analysis in Sections 2 and 3 showed that the worries over a wasteful commercial space race are overblown, conditional upon an effective legal system for establishing and enforcing celestial property claims. In addition, the legal overview in Section 4 suggested a simple way that legal system can come about.

\section{CONClusion: What Should SOVEREIGNS Do?}

The preamble to OST contains valuable information about international lawyers' and diplomats' intent to create new rights and obligations for states in the context of space activities. ${ }^{48}$ While the preamble itself does not specify any new rights and obligations, it does provide important hermeneutical context for what kind of governance regime the parties to the treaty envisaged. The preamble announces that the space governance regime should reflect the "common interest of all mankind in the progress of the exploration and use of

${ }^{48}$ Christopher Daniel Johnson, International Law Governing Outer Space Activities, in Outer Space Law: Legal Policy and Practice 1,4 (Yanal Abul Failat \& Anél Ferreira-Snyman eds., 2017). 
outer space for peaceful purposes," and that "the exploration and use of outer space should be carried on for the benefit of all peoples irrespective of the degree of their economic or scientific development..."49 Given the significant developments in the commercial space sector, now is the time to ask: is the appropriation of celestial land by private parties consistent with the purpose and object of OST?

The law and economics analysis conducted above suggests private enterprise in space, including the appropriation of celestial resources, will not have deleterious effects. The predicable economic inefficiency created by a resource race will not materialize in space. Due to heterogeneity among competitors, as well as mutual information conditions, a commercial space race can be expected to create wealth for mankind, not destroy it. Furthermore, sovereigns do not need to modify extensively the international legal environment to secure this wealth. Private companies, operating according to market-chosen law ${ }^{50}$, can and will take advantage of the commercial opportunities afforded by celestial resources. So long as these companies have a reasonable expectation that existing states will not move to seize this wealth, or penalize its creation, the prospects for a wealth-creating commercial space order are bright.

Considered in light of the above, the next natural question is, what should sovereigns do? The dominant approach focuses on modifying existing international law. Scholars recognize that private enterprise in space is a de facto certainty. Even given the legal ambiguities present in OST Articles I and $\mathrm{II},{ }^{51}$ the benefits to sovereigns tacitly allowing, if not actively encouraging, their commercial space actors to appropriate celestial resources are too great to ignore. ${ }^{52}$ This impels the push to modify international law to reflect the changed reality of space, which no longer resembles Cold War conditions. De jure rights and obligations, in this line of thinking, cannot completely surrender to de facto conditions - outer space ought not be surrendered to the clutches of realpolitik - but they should nonetheless be commensurate with these conditions. One solution is to amend public international law by creating international oversight over private parties"

49 OST, supra note 5.

${ }^{50}$ Edward Peter Stringham, Market-Chosen Law, 14 J. OF LiBERTARIAN StUdies 53 (1998); Edward P. Stringham, Private Governance: Creating Order in Economic and Social Life (Oxford Univ. Press 2015); Bruce Benson, EnTERPrise of Law Justice Without THE StATE (Indep. Inst. 2011); Salter \& Leeson, supra note 13; Salter, supra note 13; BELL, supra note 47.

${ }^{51}$ Philip De Man, The Exploitation of Natural Resources in Outer Space, in OuTER Space Law: Legal Policy and Practice 243, 254 (Yanal Abul Failat \& Anél FerreiraSnyman eds., 2017).

52 Wilan Erlank, Property and Ownership in Outer Space, in OutER SPACE LAw: LegaL Policy And Practice 1-14 (Yanal Abul Failat \& Anél Ferreira-Snyman eds., 2017). 
claims to celestial resources. However, this it is not the only solution. Rather than a top-down approach that implicitly attempts to plan the outer space legal commercial order, sovereigns can best contribute to the commercial development of space "for the benefit of all peoples" 53 by allowing a bottomup evolutionary process to govern space commerce. In this framework, law exists to ameliorate conflicts; where there is no conflict, there is no need to define and enforce rules specifying rights and obligations. Conflicts between space entrepreneurs will inevitably arise. Space may be large, but valuable martian real estate and asteroid minerals are still scarce. When conflicts do arise, private space enterprises can and should make reference to the body of legal precedents that have arisen out of similar terrestrial disputes. Because the problems of celestial resource appropriation are not fundamentally different in character from those of terrestrial resource appropriation, these precedents are a good place upon which to found a body of private and voluntary law for resolving commercial space disputes.

Sovereigns can and should remain committed to the principle that the appropriation of celestial real estate, and the extension of territorial jurisdiction thereto, is contrary to humanity's peaceful and mutually enriching experience in space. Realpolitik considerations aside, this lofty goal is achievable simply because territorial appropriation is frequently discrete and visible. The costs to any sovereign, even those with the greatest current space capacity, of flagrantly reneging on treaty obligations are quite high. But sovereigns should also direct their efforts to shoring up their domestic space regimes. This will involve making a credible commitment not to appropriate the creation of wealth by private space enterprises, nor punish the creation of this wealth. Even without the positive guarantee that sovereigns will defend their citizens' claims to celestial property rights in court, the negative guarantee that no move will be made to attenuate these rights will provide a significant incentive for celestial wealth creation.

This article has shown that the appropriation of celestial resources will not have destructive consequences for humanity. There will be a commercial space race, and it will be on net wealth-creating for humanity. Thus sovereigns should be cautiously optimistic about space as a source of social wealth creation. Private and voluntarily chosen law is well suited to govern new space commercial relationships. Thus it is important that sovereigns avoid the temptation to plan in advance what the legal regime for space ought to look like. There are a number of existing problems, such as guaranteeing all states access to orbit, further specifying liability rules, and mitigating the problems posed by space debris,${ }^{54}$ to which sovereigns ought to devote their

53 OST, supra note 5.

54 Alexander William Salter, Space Debris: A Law and Economics Analysis of the Orbital Commons, 19 Stan. TeCH. L. Rev. 221, 238 (2016). 
attention. For the time being, space commerce, including a commercial space race, does not pose a threat to international harmony or human welfare, and in fact promises to be a boon. 